\author{
Military Technical College \\ Kobry El-Kobbah, \\ Cairo, Egypt.
}

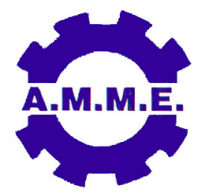

\title{
NUMERICAL INVESTIGATION OF VENTILATION SYSTEMS TO CONTROL INFECTION INSIDE OPERATING ROOMS
}

\author{
H. E. Mohamed ${ }^{1}$, T. M. Belal ${ }^{2}$ R. I. Afify ${ }^{3}$ and O. E. Abdellatif ${ }^{3}$
}

\begin{abstract}
The ventilation system of a hospital operating room is used to provide comfortable and healthy environment. The healthy environment can be achieved by minimizing the risk of contamination through filtration and air distribution scheme. This paper involves numerical study for different ventilation systems studying the effect of air distribution on bacteria diffusion and the indoor air quality by using (CFD) techniques. Five different configurations ventilation systems based on Hospital guidelines standards conditions are applied on a selected model to evaluate the efficiency of ventilation systems in minimizing the risk of postoperative infection. It is concluded that the fourth configurations (laminar airflow (LAF) and exhausts from low level at two sides exhorts) which matching with DIN and ASHRAE Standard is the most efficient which satisfies the comfort conditions and provides protection against infection.
\end{abstract}

\section{KEY WORDS}

Numerical investigation, ventilation, infection control, operating rooms, CFD.

1 Research Student, Shoubra Faculty of Engineering, Benha University.

2 Department of Mechanical Engineering, Faculty of Engineering Pharos University.

3 Department of Mechanical Eng., Shoubra Faculty of Eng., Benha University. 


\section{NOMENCLATURE}

\begin{tabular}{|c|c|}
\hline$F_{D}$ & Drag force per unit particle mass \\
\hline$f$ & Droplet radius function $\left(r_{1}, r_{2}\right)$ \\
\hline$\vec{F}$ & External body forces $[\mathrm{N}]$ \\
\hline$u_{i}$ & $\begin{array}{l}\text { Grid velocity of the moving mesh, } \\
\mathrm{m} / \mathrm{s}\end{array}$ \\
\hline$u_{i}$ & $\begin{array}{l}\text { Fluctuating velocity component, } \\
\mathrm{m} / \mathrm{s}\end{array}$ \\
\hline$t$ & Time (sec) \\
\hline$\overline{\vec{u}_{g}}$ & Mean velocity component, $\mathrm{m} / \mathrm{s}$ \\
\hline $\bar{v}$ & Mean air speed, m/s \\
\hline$\vec{J}_{j}$ & $\begin{array}{l}\text { Diffusion flux of species j } \\
{\left[\mathrm{kg} /\left(\mathrm{m}^{2} / \mathrm{s}\right)\right]} \\
\text { Effective stress tensor }[\mathrm{N}]\end{array}$ \\
\hline$\tau_{e f f}$ & \\
\hline$\vec{v}$ & Absolute velocity vector. [m/s] \\
\hline$\sigma_{n u c}^{*}$ & $\begin{array}{l}\text { Turbulent Prandtl number for } \\
\text { nuclei transport }\end{array}$ \\
\hline$\underline{\nabla}$ & Gradient \\
\hline$\mu$ & $\begin{array}{l}\text { Molecular viscosity of the fluid [N } \\
\left.\mathrm{s} / \mathrm{m}^{2}\right]\end{array}$ \\
\hline$d_{p}$ & Particle diameter \\
\hline$E$ & Flow energy [J/kgmole] \\
\hline$F_{D}\left(u-u_{p}\right)$ & $\begin{array}{l}\text { Drag force per unit particle mass } \\
{[\mathrm{N} / \mathrm{kg}]}\end{array}$ \\
\hline$F_{x} F_{y}, F_{z}$ & $\begin{array}{l}\text { External force in }(x-y-z) \\
\text { directions }\end{array}$ \\
\hline$G_{b}$ & $\begin{array}{l}\text { Generation of turbulence kinetic } \\
\text { energy due to buoyancy }\end{array}$ \\
\hline$g_{i}$ & $\begin{array}{l}\text { Component of the gravitational } \\
\text { vector in the i direction, } \mathrm{m} / \mathrm{s}^{2}\end{array}$ \\
\hline$G_{k}$ & $\begin{array}{l}\text { Generation of turbulence kinetic } \\
\text { energy due to the mean velocity } \\
\text { gradients }\end{array}$ \\
\hline$K$ & $\begin{array}{l}\text { Kinetic energy of turbulence, } \\
\mathrm{m}^{2} / \mathrm{s}^{2}\end{array}$ \\
\hline $\mathrm{k}_{\mathrm{eff}}$ & effective conductivity $(\mathrm{W} /(\mathrm{mK}))$ \\
\hline$k_{\mathrm{p}}$ & $\begin{array}{l}\text { Turbulence kinetic energy at } \\
\text { point } P, \mathrm{~m}^{2} / \mathrm{s}^{2}\end{array}$ \\
\hline
\end{tabular}

$\mathrm{K}_{\mathrm{r}} \quad$ Overall reaction rate constant.

$\mathrm{k}_{\mathrm{t}} \quad$ Turbulent thermal conductivity $(\mathrm{W} /(\mathrm{mK}))$

$\mathrm{p} \quad$ Static pressure $[\mathrm{Pa}]$

$\mathrm{Pr}_{t} \quad$ Turbulent Prandtl number for energy

$\mathrm{R}_{\mathrm{e}} \quad$ Reynolds number

$\mathrm{SF}_{6} \quad$ Sulfur hexafluoride

$\mathrm{S}_{\mathrm{k}}, \mathrm{S}_{\varepsilon} \quad$ User-defined source terms for $\mathrm{k}$ and $\varepsilon$ equations

$\mathrm{S}_{\mathrm{m}} \quad$ Mass added to the continuous phase

from the dispersed second phase [kg]

$T_{i} \quad$ Inlet temperature, ${ }^{\circ} \mathrm{C}$

$T_{r} \quad$ Removal temperature, $\stackrel{\circ}{ } \mathrm{C}$

$\mathrm{u} \quad$ Fluid phase velocity $[\mathrm{m} / \mathrm{s}]$

$u_{j} \quad$ Mean velocity component, $\mathrm{m} / \mathrm{s}$

$\mathrm{u}_{\mathrm{p}} \quad$ Particle velocity [m/s]

$Y_{M} \quad$ Contribution of the fluctuating dilatation to the overall dissipation rate

$\rho \quad$ Density of the fluid, $\mathrm{kg} / \mathrm{m}^{3}$

$\varepsilon \quad$ Turbulence dissipation rate, $\mathrm{m}^{2} / \mathrm{s}^{3}$

Abbreviations

$\mathrm{ACH} \quad$ Air changes per hour

ASHRAE American Society of Heating, Refrigerating and Air-

Conditioning Engineers

CFD Computational Fluid Dynamics

CFM Cubic feet per minute

CFU Colony-forming unit

DPM Discrete Phase Model

HEPA High Efficiency Particulate Air

LAF Laminar Air Flow

OR Operating room

SSI Surgery Site Infection 


\section{INTRODUCTION}

Improvement of the indoor air quality management and air distribution reduces the risk to patient health, and reduces the cost of expensive drug. The control of surgical-site infection requires knowledge of the source and transport of the causative organisms, more than half of clean surgical-site infection pathogens originate from normal skin flora of patients or staff. Bacteria on skin squame lint and other dusts get into the air in the operating theatre and by turbulent air currents deposit on surfaces [1, 2]. Chow and Yang [3], investigate operating rooms ventilation, airborne particles control with the health risk of the airborne bacteria released from the surgical team on the patient, and vice versa. The simulation results indicated that the particles concentrations are found very sensitive to the location of the particles sources. It is also found that the positions of the two medical lamps have a remarkable effect on the airborne particulate dispersion. Woloszyn et al [4], study the airflow patterns and the diffusion of contaminants in an operating room with a diagonal air-distribution system is subjected to both experimental measurements and numerical modeling. The numerical simulation is performed using EXP'AIR software developed by Air Liquid for analyzing air quality in operating rooms. The flows near the boundaries are represented by using the standard logarithmic law, $\mathrm{SF}_{6}$ concentrations are calculated using the conservation equation adapted to heavy gases. The experimental and numerical results of the study show that the distribution of the contaminant in an operating room, and therefore the risk to patient, depends on the geometrical parameters of the room, such as the position of the air inlet and outlet, Memarzadeh and Jiang [5], studied the airflow modeling and particle tracking methodologies the effect of geometry changes in particular, ceiling height variations in an operating room. The study shows that airflow rate in an operating room is 20-25 ACH (for ceiling heights between $2.74 \mathrm{~m}$ and $3.66 \mathrm{~m}$ ). Systems that provide laminar (unidirectional) flow regimes with both high and low exhaust represent the best option for an operating room in terms of contamination control. Hathway et al. [6] modeling the transport of infectious particles in indoor hospital environments tends to focus on respiratory diseases such as Severe acute respiratory syndrome (SARS) and Tuberculosis TB and for this reason the source of bio-aerosols is usually taken as being at the head of the patients bed. CFD is used to study the effect of airflows on the risk of transmission of infection to patient and surgical staff. The study shows necessity to consider both respiratory and activity based bio-aerosol sources, and to achieve these by using a combination of point and zonal sources to build a realistic simulation of the risks in a space.

\section{AIRFLOW MODELING}

Airflow modeling based on computational fluid dynamics (CFD), which solves the fundamental conservation equations for mass, momentum, and energy ; given as:

\section{Continuity equation:}

$$
\frac{\partial \rho}{\partial t}+\nabla \cdot(\rho \vec{v})=S_{m}
$$




\section{Momentum equation:}

$$
\frac{\partial}{\partial t}(\rho \vec{v})+\nabla \cdot(\rho \vec{v} \vec{v})=-\nabla_{p}+\nabla \cdot\left(\begin{array}{l}
\tau \\
\tau
\end{array}\right)+\rho \vec{g}+\vec{F}
$$

\section{The energy equation:}

$$
\frac{\partial}{\partial t}(\rho E)+\nabla \cdot(\vec{v}(\rho E+p))=\nabla \cdot\left(k_{e f f} \nabla T-\sum_{j} h_{j} \vec{J}_{j}+\left(\overline{\overline{\tau_{e f f}}} \cdot \vec{v}\right)\right)+S_{h}
$$

\section{Turbulence K- $\varepsilon$ Model}

The k- $\varepsilon$ model is the simplest "complete model" of turbulence consists of twoequation model. It is a semi-empirical model, and the derivation of the model equations rely on phenomenological considerations and empiricism [7].

Transport equations for standard k-epsilon model

For turbulent kinetic energy $k$

$$
\frac{\partial}{\partial t}(\rho k)+\frac{\partial}{\partial x_{i}}\left(\rho k u_{i}\right)=\frac{\partial}{\partial x_{i}}\left[\left(\mu+\frac{\mu_{t}}{\sigma_{k}}\right) \frac{\partial k}{\partial x_{j}}\right]+G_{k}+G_{b}-\rho \varepsilon-Y_{M}+S_{k}
$$

For dissipation $\epsilon$

$$
\frac{\partial}{\partial t}(\rho \varepsilon)+\frac{\partial}{\partial x_{i}}\left(\rho \varepsilon u_{i}\right)=\frac{\partial}{\partial x_{i}}\left[\left(\mu+\frac{\mu_{t}}{\sigma_{\varepsilon}}\right) \frac{\partial \varepsilon}{\partial x_{j}}\right]+G_{1 \varepsilon} \frac{\varepsilon}{k}\left(G_{k}+C_{3 \varepsilon} G_{b}\right)-G_{2 \varepsilon} \rho \frac{\varepsilon^{2}}{k}+S_{\varepsilon}
$$

where

Turbulent viscosity is modeled as

$$
\mu_{t}=\rho C_{\mu} \frac{k^{2}}{\epsilon}
$$

Production of $\mathrm{k}$

$$
\begin{gathered}
P_{k}=-\rho \overline{u_{i}^{\prime} u_{j}^{\prime}} \frac{\partial u_{j}}{\partial x_{i}} \\
P_{k}=\mu_{t} S^{2}
\end{gathered}
$$

where $S$ is the modulus of the mean rate-of-strain tensor, defined as

$$
S \equiv \sqrt{2 S_{i j} S_{i j}}
$$

Effect of buoyancy

$$
P_{b}=\beta g_{i} \frac{\mu_{t}}{\operatorname{Pr}_{t}} \frac{\partial T}{\partial x_{i}}
$$

where $\mathrm{Pr}_{\mathrm{t}}$ is the turbulent Prandtl number for energy and gi is the component of the gravitational vector in the ith direction. For the standard and realizable - models, the default value of Prt is 0.85 .

The coefficient of thermal expansion, $\beta$, is defined as: 
Model constants

$$
\beta=-\frac{1}{\rho}\left(\frac{\partial \rho}{\partial T}\right)_{p}
$$

$$
C_{1 \epsilon}=1.44, \quad C_{2 \epsilon}=1.92, \quad C_{3 \epsilon}=-0.33, \quad C_{\mu}=0.09, \quad \sigma_{k}=1.0, \quad \sigma_{\epsilon}=1.3
$$

Particles Force Balance the Lagrangian discrete phase's model in the CFD code follows the Euler-Lagrange approach. For $\mathbf{x}$-direction it takes the following form

$$
\frac{d u_{p}}{d t}=F_{D}\left(u-u_{p}\right)+\frac{g_{x}\left(\rho_{p}-\rho\right)}{\rho_{p}}+F_{x}
$$

where

$$
F_{D}=\frac{18 \mu}{\rho_{p} d_{p}^{2}} \frac{C_{D} \operatorname{Re}}{24}
$$

\section{NUMERICAL MODEL}

In the present work, numerical study for operating room ventilation model is investigated using Computational fluid dynamics (CFD). The commercial software FLUENT (6.2.16) (CFD program) and GAMBIT (2) are used. The model of the current study, the locations of the surgical staff, medical lamps and equipment relative to the operating table were made reference to the DIN 4799 and release rate of thermal energy (W)( Human body $100 \mathrm{~W}$ or surface temperature $27^{\circ} \mathrm{C}$, Medical main lamp $280 \mathrm{~W}$, Medical satellite lamp $160 \mathrm{~W}$ and Medical equipment $2 \times 250 \mathrm{~W}$ )specification [8]. Figure (1) shows an isometric view of the operating room model with three dimension view.

\section{Grid Independency}

For the grid independence study, different mesh sizes are considered. Each case is represented by a nominal element size chosen among the values $0.2 \mathrm{~m}, 0.1 \mathrm{~m}, 0.09$ $\mathrm{m}, 0.085 \mathrm{~m}$, and $0.08 \mathrm{~m}$ respectively. These nominal elements sizes result in the corresponding meshes with the number of elements of $43511,390315,397833$, 493390 , and 521232 respectively. Figure (2) shows how the representative air average temperature in the room becomes independent from the mesh size as the number of elements increases (the nominal elements size decreases). Figure (2) presents the values of mean temperature as function of mesh size. It demonstrates that as the number of elements increases over 397833, mesh independence of the numerical solution is achieved. The mesh with 493390 elements (nominal element size of $0.085 \mathrm{~m}$ ) is found quite adequate for accurate numerical prediction. Therefore, the nominal element size of $0.085 \mathrm{~m}$ is used for generating the meshes for all the simulations presented

\section{Validation of the Flow Patterns in Operating Room}

The numerical validation and verification of the used CFD code with selected work published in literature [3]. Figures (3) and (4) show the temperature distribution of the simulation at two vertical planes $X(x=3.125 \mathrm{~m})$ and $Z(z=2.1 \mathrm{~m})$. Planes $X$ and $Y$ are 
the orthogonal planes of symmetry cutting across the operating table. As shown in figures $(3,4)$ the maximum error in temperature distribution about $4 \%$, these errors because of different in some assumptions such as room walls temperature, the outlet temperature.

\section{Validation of the Bacteria Distribution}

Liu et al [9] investigate an alternative of horizontal airflow pattern and the airflow performance in an OR, evaluated the effectiveness of the horizontal unidirectional airflow to control infectious airborne particles through onsite test and computational fluid dynamics (CFD) simulate the zone under the horizontal air supply system. Airborne particles are the main carriers of bacteria that cause post-operative infection and there is a close relationship between the colony-forming unit (CFU) and the counts of particles with diameter $5 \mu \mathrm{m}$ [10]. The main source of bacteria in OR is skin scales or particles ranged from 5 to $10 \mu \mathrm{m}$ in diameter. Uniform distribution of diameter of $5 \mu \mathrm{m}$ was assumed as the infectious particle diameter, harmful particles released by surgeons and patient in OR. The diversity of particulate density was supposed to be $2 \mathrm{~g} / \mathrm{cm} 3$ in this study [9]. Ultra clean air was supplied from a fan-filter unit. The total particulate release rate is set to be 600 particles/min equal to (1.31 $\left.\times 10^{-12} \mathrm{~kg} / \mathrm{s}\right)$ for a surgeon and 400 particles $/ \mathrm{min}$ equal to $\left(8.72 \times 10^{-13} \mathrm{~kg} / \mathrm{s}\right)$ for a patient .The RANS equations and standard $k-\varepsilon$ model are employed to calculate the airflow field in the OR, and the result is used for both evaluating airflow pattern and calculating particulate transportation. Fluent was used as a solver in the numerical simulation The two Figures (5) and (6) show considerable agreement between their results and the present work Error in the distribution of bacteria and about $14 \%$ of these errors occurred because of a difference in assumptions such as, the arrangement distances, the people dimensions and different grid size. After complete comparison between the used numerical CFD model with other numerical CFD models as indicated in the previous sections. This comparison shows a good agreement between current model and compared models.

\section{Modeling Considerations}

Different configurations ventilation systems based on Hospital guidelines standards conditions are applied on the selected base model [3] to study their effects on the model parameters using CFD. These systems configurations outline studied by Memarzadeh [11]. Configuration 1, 2 as shown in figure (7) uses conventional grilles as the basis of the ventilation system, which provides jets at a (relatively) high velocity at discrete locations in the room. Configuration 3, 4 and 5 provide variations on a laminar flow type ventilation system as shown in figures (which aim to provide vertically downward flow conditions. The different between the cases are typically associated with differences in diffuser array size.

\section{Boundary conditions}

The boundary conditions are listed in table (1). The people, medical equipment and lamps are treated as solid blocks with heat as described in the base model for validation [3] )( Human body $100 \mathrm{~W}$ or surface temperature $27^{\circ} \mathrm{C}$, Medical main lamp $280 \mathrm{~W}$, Medical satellite lamp $160 \mathrm{~W}$ and Medical equipment $2 \times 250 \mathrm{~W}$ ). For bacteria boundary conditions, the main source of bacteria in operating rooms is skin 
scales or particles a uniform particles diameter of $5 \mu \mathrm{m}$ was assumed as the infectious particles, the diversity of particulate density was supposed to be $2 \mathrm{~g} / \mathrm{cm}^{3}$ [9]. Because the surgeons wearing sterile clothes preventing particulate release, particles assumed to be released from a part of their faces. For the patient, the release was focused at three positions the head, the wound, and the feet. the total particulate release rate was set to be $\left(1.31 \times 10^{-12} \mathrm{~kg} / \mathrm{s}\right)$ for Human body and $4.9 \times 10^{-}$ ${ }^{12} \mathrm{~kg} / \mathrm{s}$ ) for wound [9]. The five configurations conditions summered in table (1). This section displays and discuss the CFD results for every configuration system. The results study includes the analysis of airflow temperature distribution and particles (bacteria) traces. The figures show the CFD results are available for all three dimensions, however the figures illustrate the results only in two sections; the first use a vertical section at the center plan of the operating table $z=2.1 \mathrm{~m}$. The particles results will display the particles traces in the whole operating room to study the possibility of infection from patient to staff and the infection from the staff to the patient due to the direction of bacteria motion.

\section{First Configuration:}

\section{Configuration description}

Conventional Air is supplied at high level (one side), exhausted at low (two sides) as shown in figure (9-a) and table (1). The air diffusers throw the air at high level with small offset from the ceiling and sidewalls due to Coanda effect. The two air jets from both diffusers move further along the ceiling and sidewalls forming two sides attached jets. Because of both the lower temperature of the air jets comparing with the occupied zone and the jet velocity decay, the air jets drops nearby the facing end wall under the effect of buoyancy forces. Both jets bind together in one stream causing eddies in the side of the table and above the patient causing high turbulence flow in operating area. High eddies and recirculation zones at the surgical area and above the patient. Because of the location of conditioned air diffuser away from the operating area the air reach the operating area at low velocity which is uncomfortable for staff and patient and does not achieve washing effect (The velocity at the operating area should subsequently provide a washing effect for removing larger particles with minimum velocity $(0.17 \mathrm{~m} / \mathrm{s}-0.25 \mathrm{~m} / \mathrm{s})$ for any contaminant in the air can be immediately removed [15].

\section{Configuration results}

Because of low velocity air the temperature rise in the operating area. Figure (8) shows high temperature in the operating area and low temperature areas in upper two sides due to jet air low temperature. Figure (9) shows the particles (bacteria) tracks from patient as particles source The airborne particles moving in air streams due to air direction the particles traces show that the particles path in the staff direction causing high exposure risk for surgical staff. Figure (10) shows the particles (bacteria) tracks from staff as particles sources. The particles track path away from the patient, but it path through the Staff breathing level in the right side causing high exposure risk of the surgical staff infections.

\section{Second Configuration:}

\section{Configuration description}

(Low supply/ high exhaust Conventional system) Second configuration design is 
conventional system with low supply and high exhaust) as shown in figure (9-b) and table (1). The air diffusers throw the air at low level in two sides with small offset from the floor and sidewalls due to Coanda effect. The air jets from diffusers move along the low level forming four sides attached jets causing high recirculation and turbulence flow around operating area causing high turbulence flow around operating area and above the patient body. Because of the location of conditioned air diffuser away from the operating area the air reach the operating area at low velocity which is uncomfortable for staff and patient which does not remove the bacteria particles and the washing effect and does not achieved [16].

\section{Configuration results}

Because of low velocity air the temperature rise in the operating area. As shown in figure (11) which represents temperature distribution in the middle plan $(z=2.1 \mathrm{~m})$. The particles moving as airborne in the air stream air direction. Figure (12) Show the particles (bacteria) path from patient as particles sources, the particles path through the breathing level of staff1 causing high exposure risk to the surgical staff1 infections, Figure (15) Show the particles (bacteria) path from staff as particles sources. The particles moving upward away from the patient except staff 5 source particles move toward the patient which could cause infection to the patient.

\section{Third Configuration:}

\section{Configuration description}

The third configuration design the conditioned air diffused from the ceiling ) as shown in figure (9-c) and table (1) to apply Laminar airflow (LAF) which means that airflow is predominantly unidirectional when did not obstructed and directed vertically from the ceiling. The inlet condition in this configuration complies with the German standard DIN 1946/4 (1999) standard [14] and the inlet conditions for this case matching ASHRAE Standard 170, [13]. The air throws from the ceiling by two diffusers. Then air path through the screen which is array of perforated panels located above the operating table furnishes the room with unidirectional air stream at the face of the panels. The unidirectional air streams from the two diffusers causing the air to be laminar and there is no recirculation or eddies in the operating area.

\section{Configuration results}

The temperature distribution as shown in figure (14) indicate good temperature in the operating area $\left.293.2 \mathrm{~K}=20.2^{\circ} \mathrm{C}\right)[8,12,13,16,17]$. The unidirectional air pushes the particles and moving it down away from operating table and away from the breathing of the staff as shown in figures (15) and (16) due to the air momentum. Then the particles spread in the whole operating room as shown figures (15) and figure (16) by observing the particles movement in the left, we find that the particles continue moves in the air streams until it reach the wall then the particles reflect its direction moving in the air streams until it reach the outlet diffusers .By observing the movement of the particles in the right, the particles move in the direction of the wall and then the particles reflect its direction moving in the air streams. The particles move in the air streams to get to the outlets diffuser, which is located in the other side of the room. The particles try to passes through the projection area, but the unidirectional air which coming from the ceiling prevents the particles to path in the operating area. After that the particles moves around the operating area in order to 
reach the outlet diffusers. The staff which stands away from the air projection area may be expose to infection.

\section{The Fourth Configuration:}

\section{Configuration description}

The fourth configuration design apply laminar airflow (LAF) diffusing as shown in figure (9-d) and table (1) the conditioned air from the ceiling like third configuration but the exhausts at two sides low level to study the effect of outlet location. The unidirectional air streams from the two diffusers causing the air to be laminar and there is no recirculation or eddies in the operating area.

\section{Configuration results}

The temperature distribution as shown in figure (17) indicate standard temperature in the operating area $\left(293.2 \mathrm{~K}=20.2^{\circ} \mathrm{C}\right)[8,12,13,17,18]$. The unidirectional air pushes the particles and moving it down away from operating table and away from the breathing of the staff as shown in figures (18) and (19) due to the air momentum. Then the particles spread in sides of the operating room. By observing the particles movement in the left, find that the particles continue moves in the air streams until they reach the wall then the particles reflect their direction moving in the air streams until they reach the outlet diffusers in the two sides. The particles try to passes through the projection area, but the unidirectional air which coming from the ceiling prevents the particles to path in the projection area.

\section{The Fifth Configuration:}

\section{Configuration description}

The fifth configuration design apply laminar airflow (LAF) by diffuse the conditioned air from the ceiling like third and fourth configurations but the exhausts at two sides high level to study the effect of outlet location. The unidirectional air streams from the two diffusers causing the air to be laminar and there is no recirculation or eddies in the projection area.

\section{Configuration results}

The temperature distribution as shown in figure (20) indicate suitable temperature in the projection area $\left(292 \mathrm{~K}=19^{\circ} \mathrm{C}\right.$ and $\left.293.4 \mathrm{~K}=20.2^{\circ} \mathrm{C}\right)[8,12,13,16,17]$. By observing figure (21) low temperature zone which is non- occupied zone in the right hand side. The unidirectional air pushes the particles and moving it down away from operating table and away from the breathing of the staff as shown in figures (21) and (22) due to the air momentum. Then the particles spread in sides of the operating room as shown figures (21) and figure (22) by observing the particles movement in the left, find that the particles continue move in the air streams until they reach the wall then the particles reflect their direction moving in the air streams until they reach the outlet diffusers in the two sides. The particles try to passes through the projection area, but the unidirectional air which coming from the ceiling prevents the particles to path in the projection area. 


\section{Summary of Results}

By comparing between the five systems one can observe that laminar flow type ventilation system (configurations $3,4,5$ ) better than conventional ventilation system (configurations 1,2 ) in terms of the air velocity distribution, temperature distribution in projection area and the particles distribution .By comparing the three laminar flow configurations systems $(3,4$, and 5$)$ observe that the results for air distribution and the air velocity are similar, but the configurations $(3,4)$ are the best in terms of the temperature distribution. In terms of the particles of bacteria distribution one can observe that, configurations $(3,4)$ are best where the patient and staff do not expose to the risk of infections Therefore concludes that the best configuration is the fourth which satisfies the comfort conditions and provides protection against infection.

\section{CONCLUSION}

- Laminar unidirectional air is the best inlet condition which gives suitable condition in the projection area and achieves the washing effect of the bacterial particles.

- The locations of the exhausts effect on the airflow pattern and the temperature distribution and consequently effecting on the bacteria particles paths which effect on the probability occurrence of infection.

- The air exhausts should be distributed in more than one side to avoid the long presence of bacteria in the air and to shorten the particles paths to arrive the outlet

\section{REFERENCES}

1. S. Dharan and D. Pittet, "Environmental controls in operating theatres" Journal of Hospital Infection (2002) 51:79-84

2. Tin-Tai Chow, Xiao-Yu Yang "Ventilation performance in operating theatres against airborne infection: review of research activities and practical guidance" Journal of Hospital Infection (2004) 56, 85-92

3. Tin-Tai Chow, Xiao-Yu Yang "Performance of ventilation system in a nonstandard operating room", Building and Environment 38 (2003) 1401 - 411

4. Woloszyna .M, Virgone. J and Mélen. S. "Diagonal air-distribution system for operating rooms: experiment and modeling" Building and Environment 39 (2004) $1171-1178$.

5. Memarzadeh. F and Jiang, Z, "Effect of Operation Room Geometry and Ventilation System Parameter Variations on the Protection of the Surgical Site" American Society of Heating, Refrigerating and Air-Conditioning Engineers / 2004 Product Code(s): D-22548

6. Hathway .A, Noakes. C and Sleigh A " CFD modelling of a hospital ward: Assessing risk from bacteria produced from respiratory and activity sources" Indoor Air 2008, 17-22 August 2008, Copenhagen, Denmark - Paper ID: 45

7. B. E. Launder and D. B. Spalding, "Lectures in Mathematical Models of Turbulence"; Academic Press, London, England, 1972.

8. DIN. 1990. DIN 4799, Luftfuhrungssyteme fur Operationsraume. 
9. Liu J, Wang $\mathrm{H}$, Wen $\mathrm{W}$ "Numerical simulation on a horizontal airflow for airborne particles control in hospital operating room" Building and Environment 44 (2009) 2284-2289

10. Rui Z, Guangbei. T and Joshing. L "Study on biological contaminant control strategies under different ventilation models in hospital operating room" Building and Environment 43 (2008) 793-803

11. Méndez, C, José, J.F. S, Villafruela J.M and Castro, F "Optimization of a hospital room by means of CFD for more efficient ventilation" Energy and Buildings 40 (2008) 849-854

12. NHS Estates. Health technical memorandum 2025"design considerationsventilation in healthcare premises. London" HMSO; 1994.

13. ASHRAE. Standard 170, "Ventilation of Health Care Facilities" - Public Review Draf. 2005

14. DIN 1946/4 (1999) standard

15. NHS Estates. Health technical memorandum 2025"design considerationsventilation in healthcare premises. London" HMSO; 1994.

16. Khalil .E.E "Energy Efficiency, Air Flow Regime and Relative Humidity in AirConditioned Surgical Operating Theatres" Proceedings " ASHRAE, Paper ASHRAE-2012-CH-12-C056, January 2012

17. Centers for Disease Control and Prevention (CDC and HICPAC) and the Healthcare Infection Control Practices Advisory Committee (HICPAC).

18. "Guidelines for Environmental Infection Control in Health-Care Facilities". 2003.

Table (1) Details of Cases Considered in Study.

\begin{tabular}{|c|c|c|c|c|}
\hline System disruption & Diffuser Details & $\begin{array}{l}\text { Volume } \\
\text { Flow Rate } \\
\left(\mathrm{m}^{3} / \mathrm{s}\right)\end{array}$ & $\begin{array}{c}\text { Supply } \\
\text { Temperatur } \\
\text { e }\end{array}$ & $\begin{array}{l}\text { Supply } \\
\text { Velocity }\end{array}$ \\
\hline $\begin{array}{l}\text { 1. (conventional) Air is supplied at } \\
\text { high level (one side), exhausted at low } \\
\text { (two sides) as shown in figure ( } 9 \text {-a). }\end{array}$ & $\begin{array}{c}\text { Supply and } \\
\text { exhaust grilles } \\
(0.61 \mathrm{~m} \times 0.36 \\
\mathrm{m})\end{array}$ & $0.71 \mathrm{~m}^{3} / \mathrm{s}$ & $19.7^{\circ} \mathrm{C}$ & $1.63 \mathrm{~m} / \mathrm{s}$ \\
\hline $\begin{array}{l}2 . \quad \text { (Conventional ) Air is supplied } \\
\text { at low level (two side), exhausted at high } \\
\text { level (two sides) as shown in figure (9- } \\
\text { b). }\end{array}$ & $\begin{array}{c}\text { Supply and } \\
\text { exhaust grilles } \\
(0.61 \mathrm{~m} \times 0.36 \\
\mathrm{m})\end{array}$ & $0.71 \mathrm{~m}^{3} / \mathrm{s}$ & $19.7^{\circ} \mathrm{C}$ & $1.63 \mathrm{~m} / \mathrm{s}$ \\
\hline $\begin{array}{l}\text { Laminar (mixed level exhausts) } \\
\text { Exhaust grilles are located on one side } \\
\text { and high and low level as shown in } \\
\text { figure }(9-\mathrm{c})\end{array}$ & $\begin{array}{c}\text { Two inlet } \\
\text { diffusers [1.83 } \\
\mathrm{m} \times 1.22 \mathrm{~m}]\end{array}$ & $0.76 \mathrm{~m}^{3} / \mathrm{s}$ & $19.8^{\circ} \mathrm{C}$ & $0.17 \mathrm{~m} / \mathrm{s}$ \\
\hline $\begin{array}{l}\text { 4. Laminar (high level exhausts) } \\
\text { Exhaust grilles are located on high level } \\
\text { as shown in figure (9-d) }\end{array}$ & $\begin{array}{c}\text { Two inlet } \\
\text { diffusers }[1.83 \\
\mathrm{m} \times 1.22 \mathrm{~m}]\end{array}$ & $0.76 \mathrm{~m}^{3} / \mathrm{s}$ & $19.8^{\circ} \mathrm{C}$ & $0.17 \mathrm{~m} / \mathrm{s}$ \\
\hline $\begin{array}{l}\text { 5. Laminar (low level exhausts) } \\
\text { Exhaust grilles are located on low level } \\
\text { sc chnom in firı irs (a_al }\end{array}$ & $\begin{array}{c}\text { Two inlet } \\
\text { diffusers }[1.83 \\
m \sim 1 \text { ว } \mathrm{ml}\end{array}$ & $0.76 \mathrm{~m}^{3} / \mathrm{s}$ & $19.8^{\circ} \mathrm{C}$ & $0.17 \mathrm{~m} / \mathrm{s}$ \\
\hline
\end{tabular}




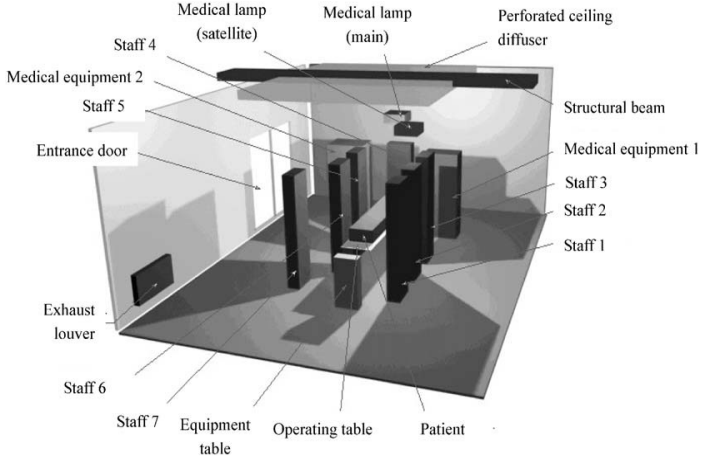

Figure (1). Isometric view of the operating room reference model

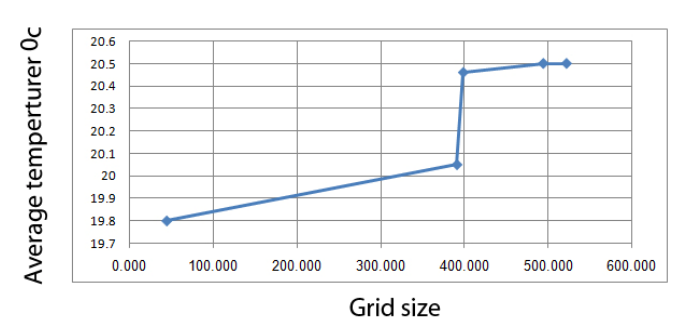

Figure (2). Effect of mesh size on average temperature results.

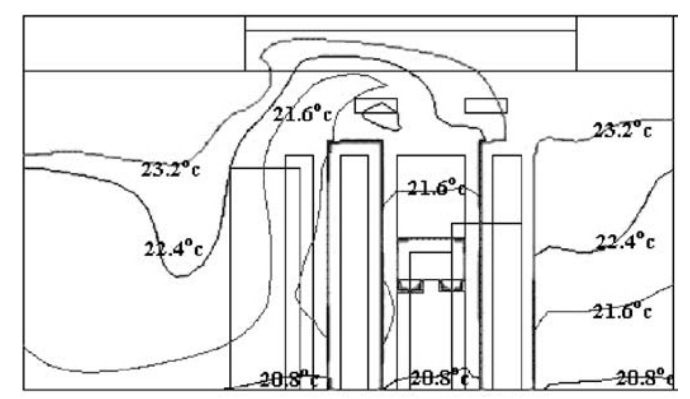

Figure (3-a) Temperature contour for reference model [3] in Plane X;

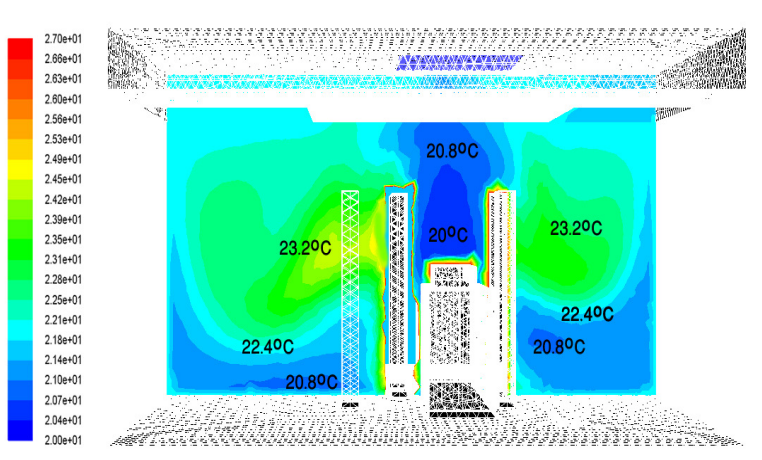

Figure (3-b). Temperature contour for Base model Plane $X$;

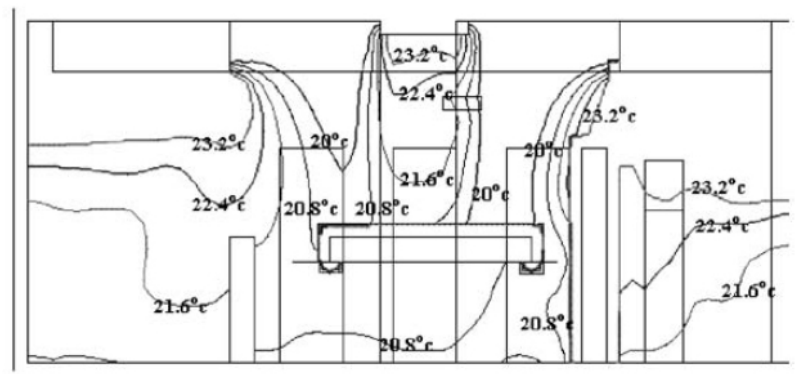

Figure (4-a). Temperature contour maps for reference model Plane $z$

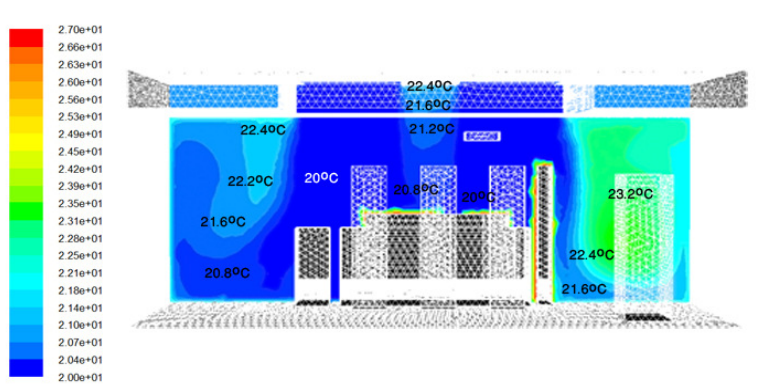

Figure (4-b). Temperature contour maps for base mode plan z

Figure (4). Temperature contour. 


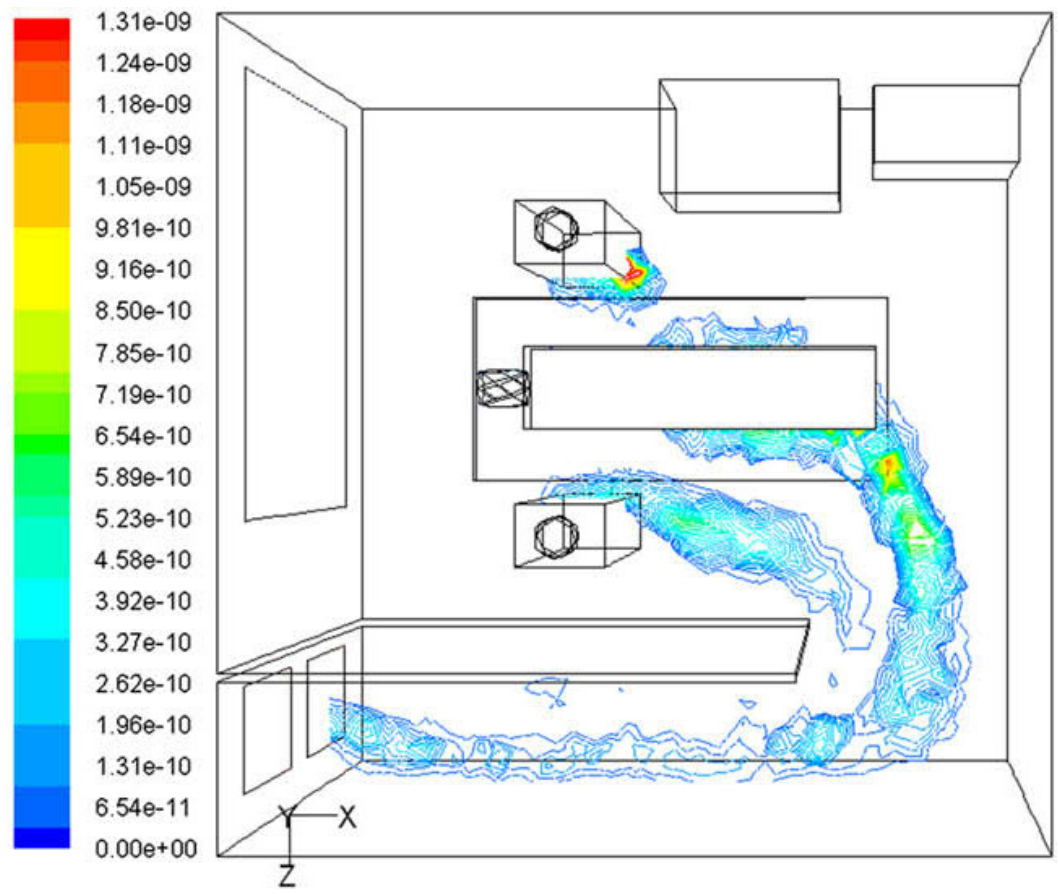

Figure (5). plane view (Particle concentration field for Liu et al. work [9]).

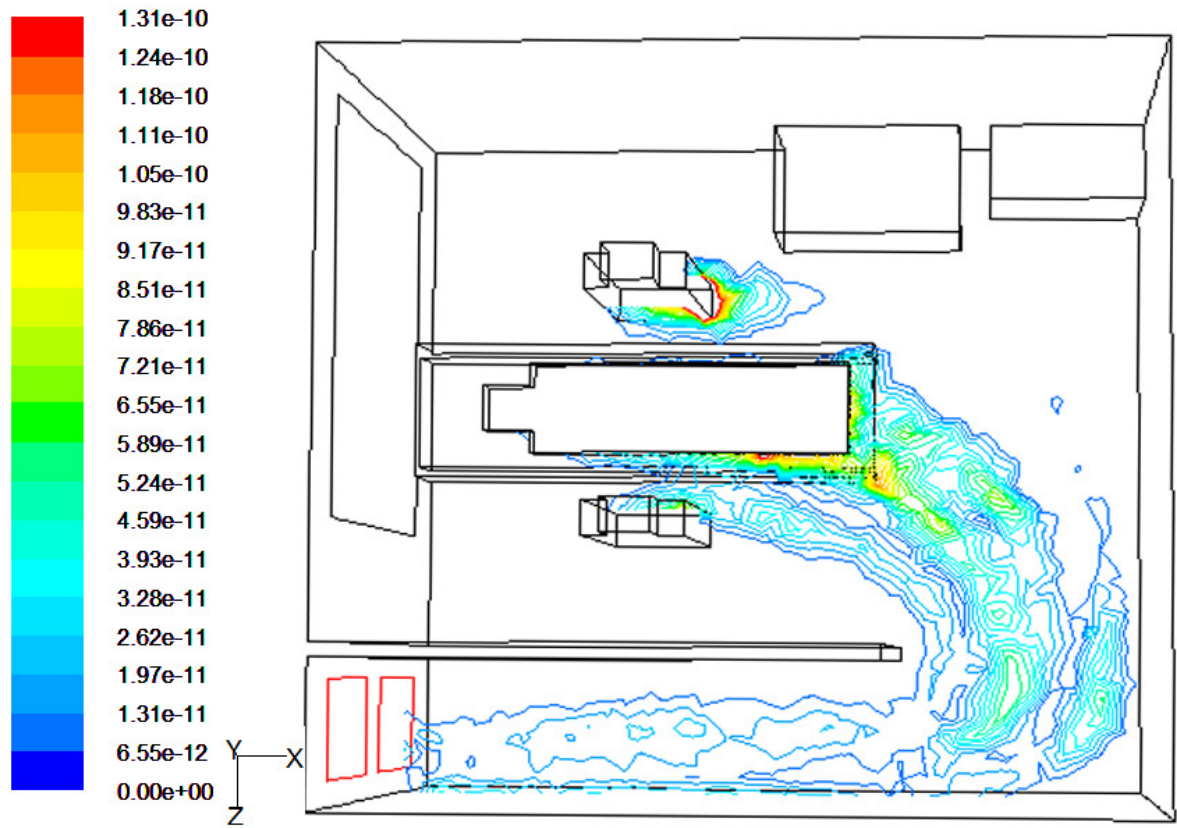

Figure (6). plane view (Particle concentration field for the present work). 


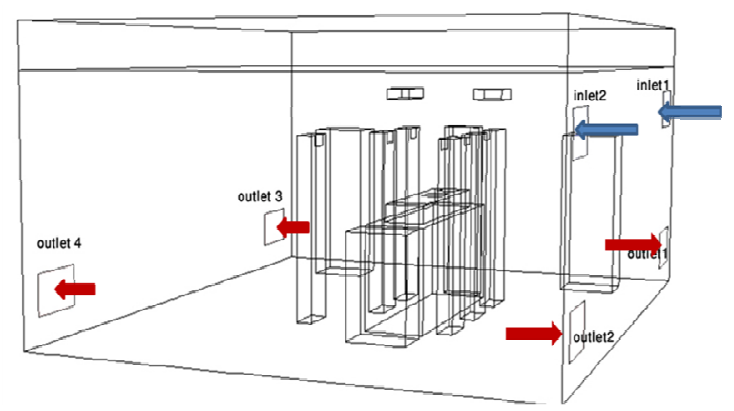

(a) First Configuration (Air is supplied at high level (one side), exhausted at low level two sides).

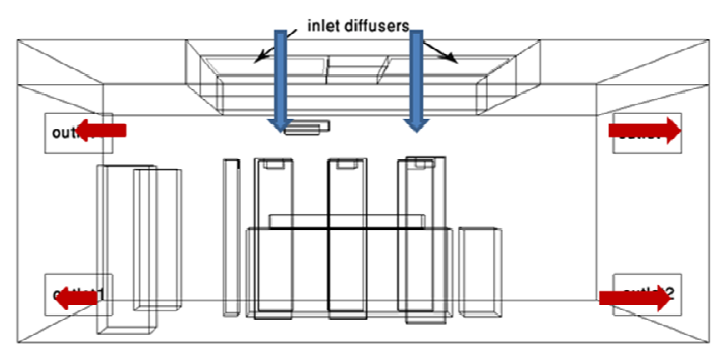

(c) third Configuration with Exhaust grilles are located on two one side and high and low level.

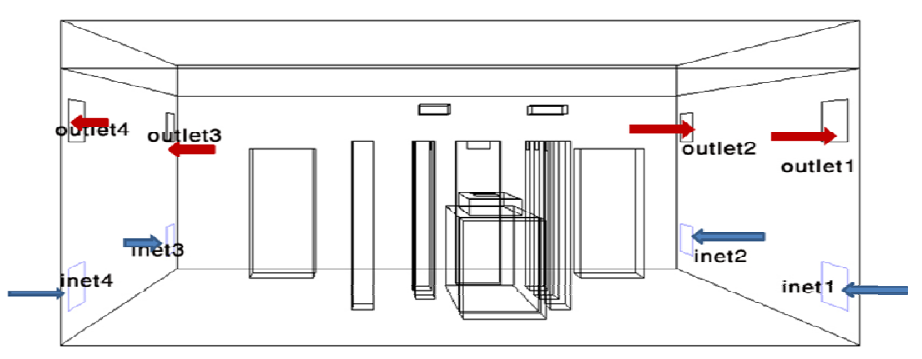

(b) Second Configuration (Air is supplied at low level (two side), exhausted at high level two side.

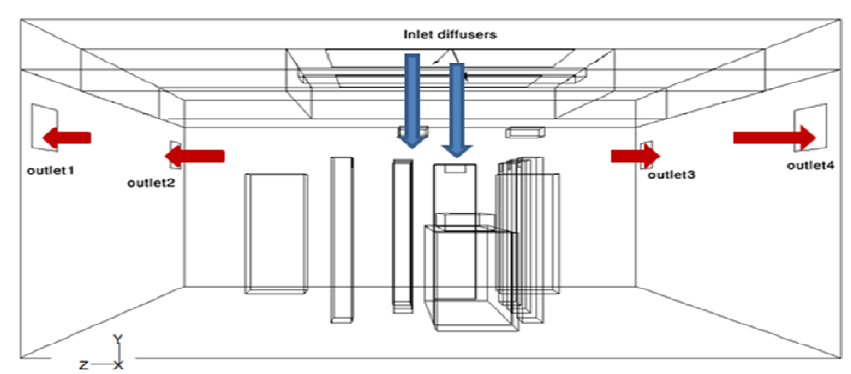

(d) fourth Configuration Exhaust grilles are located on two side and high level

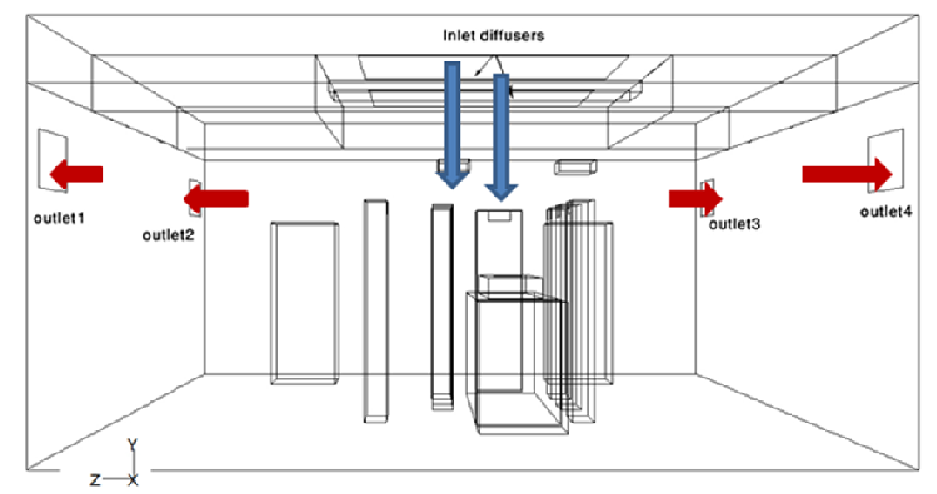

(e) fifth Configuration (Exhaust grilles are located on two side and high level).

Figure (7) five configurations ventilation systems. 

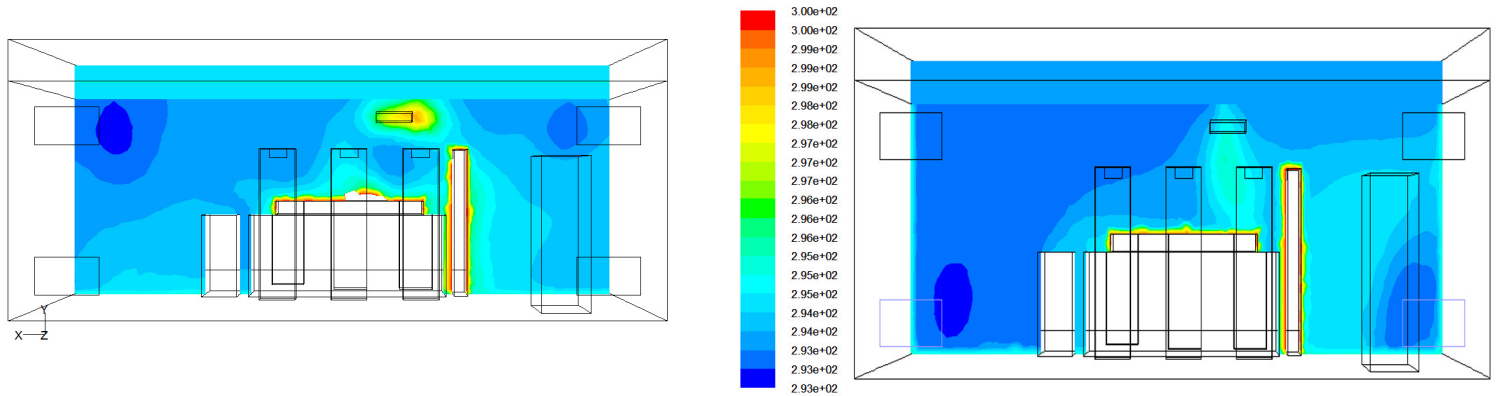

Figure (8). contours of static temperature for first configuration $\mathrm{z}=2.1 \mathrm{~m}$

Figure (1.1) contours of static temperature for second configuration (a) plane $x=3.1 .25 \mathrm{~m}$ (b) $\mathrm{z}=2.1 \mathrm{~m}$.
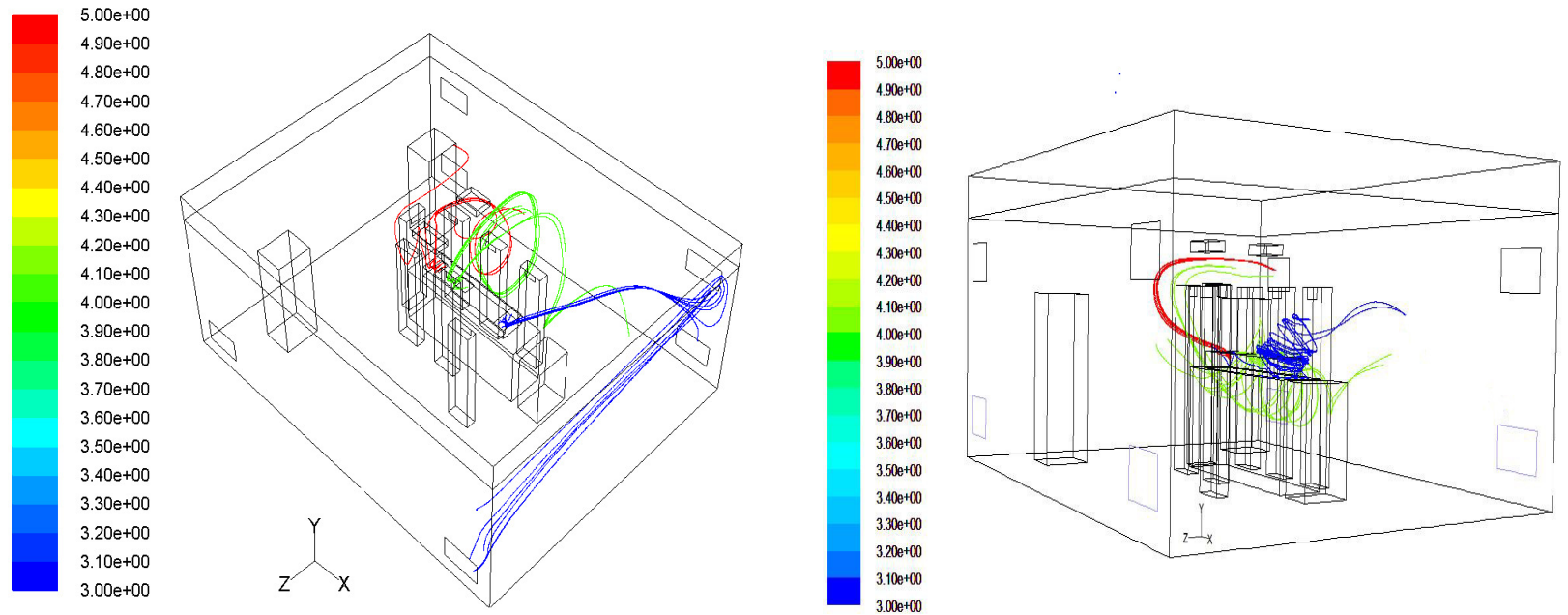

Figure (9). particles (bacteria) traces colored by surface ID for patient as particles sources in first configuration.

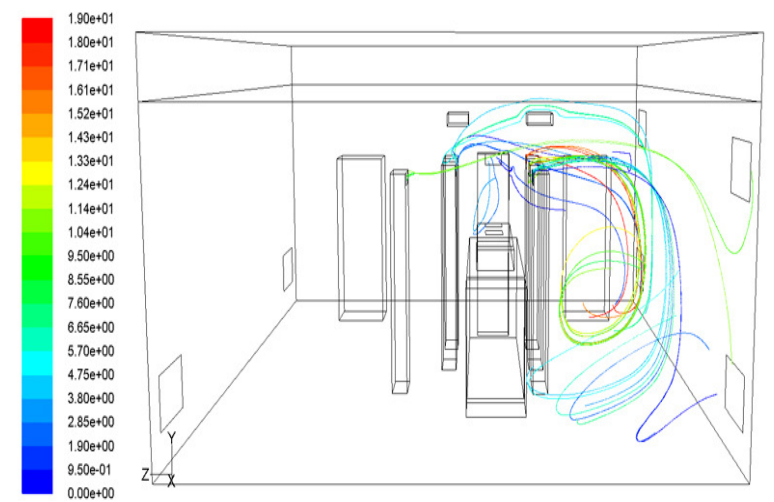

Figure (10). particles (bacteria) traces colored by surface ID for staff as particles sources in first configuration.

Figure (12). particles (bacteria) traces colored by surface ID for patient as particles sources in second configuration.

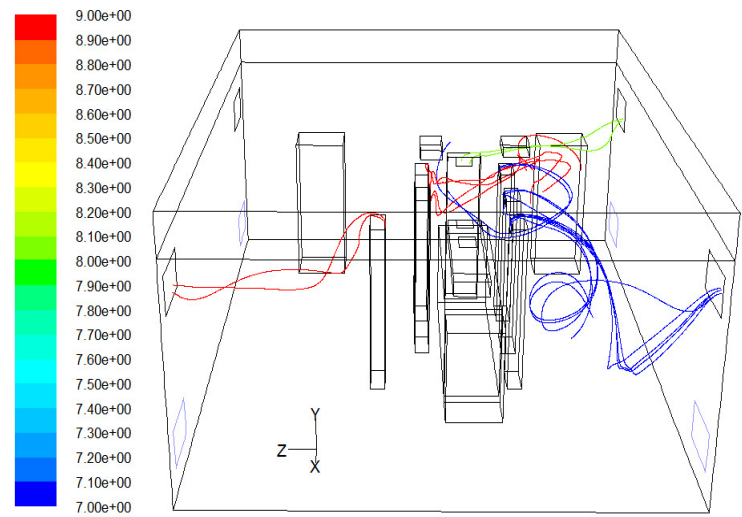

Figure (13). particles (bacteria) traces colored by surface ID for staff as particles sources in second configuration 


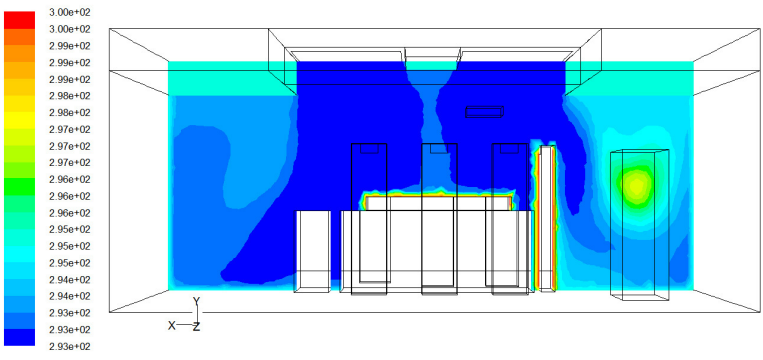

Figure (14). contours of static temperature to third configuration $z=2.1$.
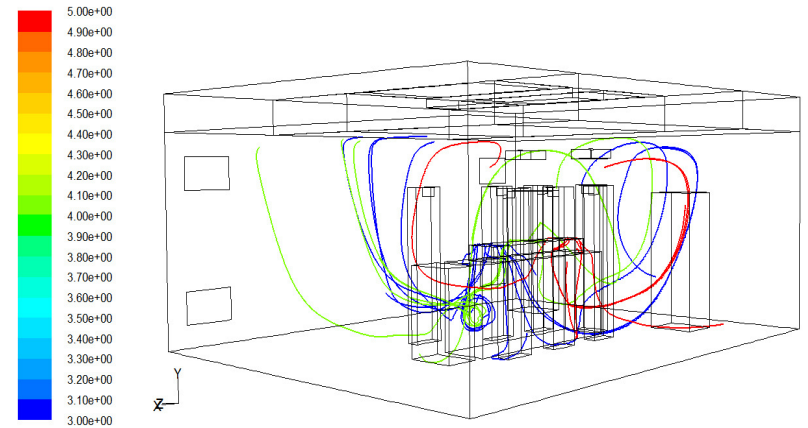

Figure (15). particles (bacteria) traces colored by surface ID for patient as particles sources to the third configuration.
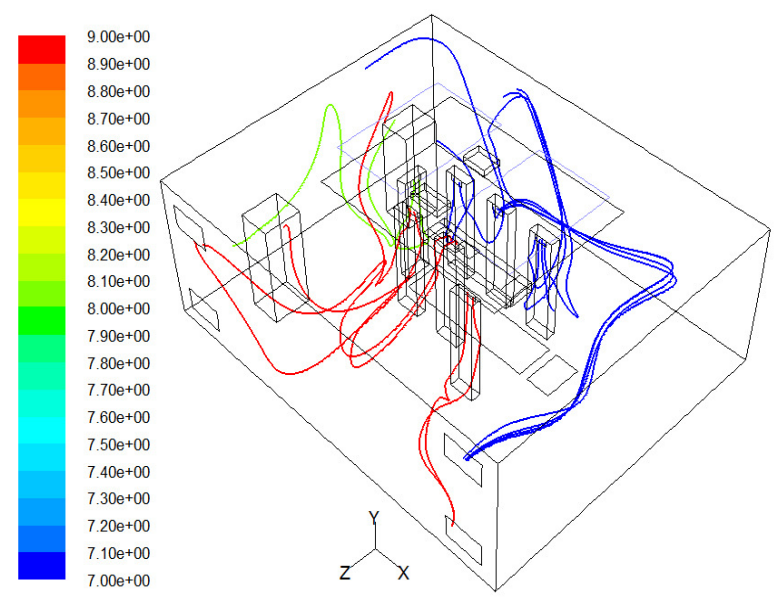

Figure (16). particles (bacteria) traces colored by surface ID for staff as particles sources in third configuration.

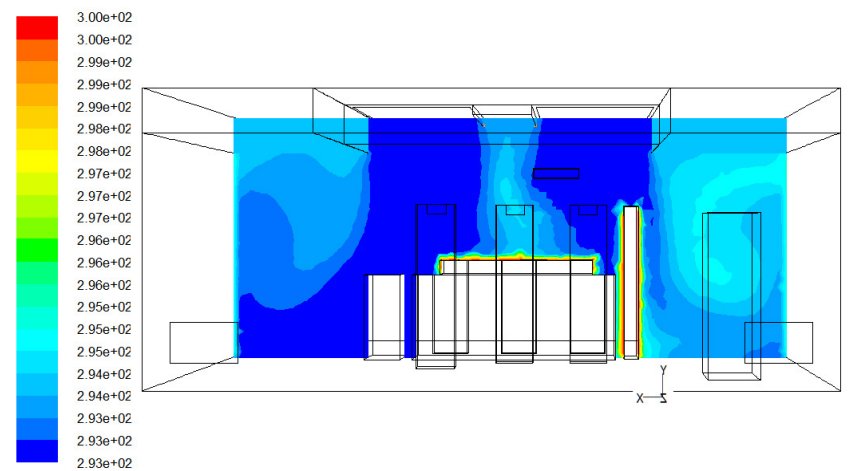

Figure (17). contours of static temperature for the fourth configuration $\mathrm{z}=2.1 \mathrm{~m}$.
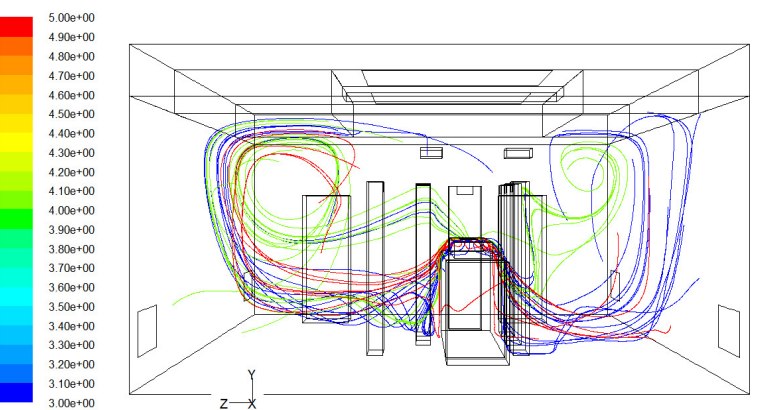

Figure (18). particles (bacteria) traces colored by surface ID for patient as particles sources in fourth configuration.

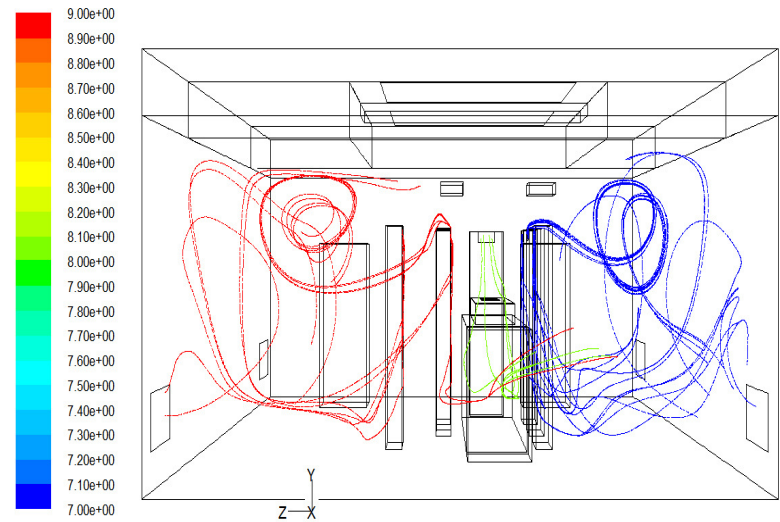

Figure (19). particles (bacteria) traces colored by surface ID for staff as particles sources in fourth configuration. 


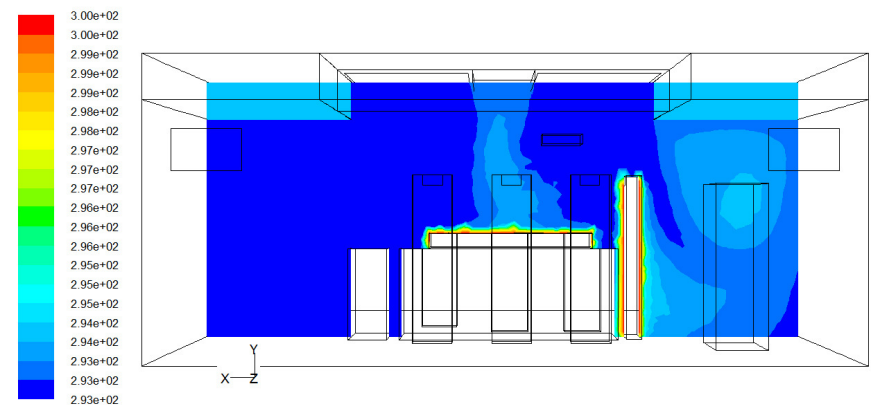

Figure (20). contours of static temperature to fifth configuration $z=2.1 \mathrm{~m}$

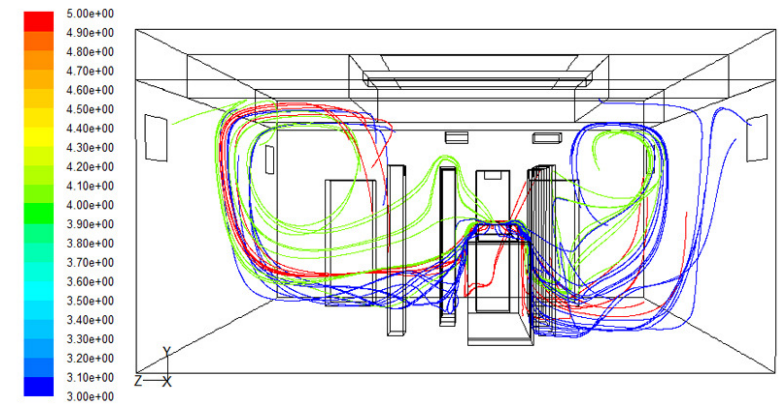

Figure (21). particles (bacteria) traces colored by surface ID for patient as particles sources in fifth configuration.

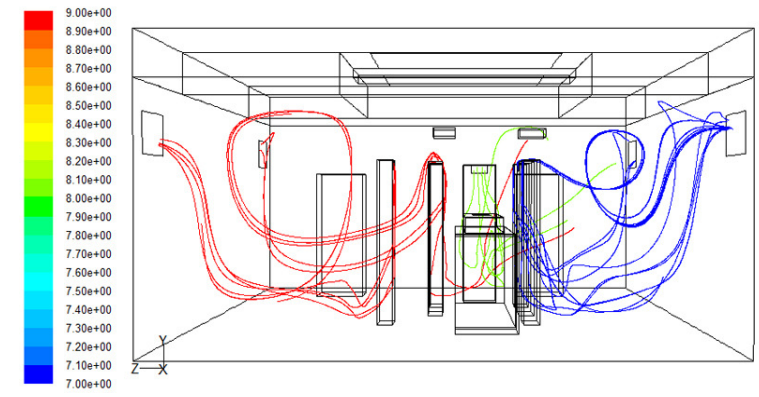

Figure (22). particles (bacteria) traces colored by surface ID for staff as particles sources in fifth configuration. 